\title{
Understanding public and stakeholder attitudes in pollinator conservation policy development
}

\author{
by \\ Allison Nicholls \\ supervised by \\ Sheila Colla
}

\begin{abstract}
A Major Paper
submitted to the Faculty of Environmental Studies

in partial fulfillment of the requirements for the degree of Master in Environmental Studies

York University, Toronto, Ontario, Canada
\end{abstract}

July 2017 


\section{Foreword (relation to Plan of Study)}

My research involved a case study in environmental management specifically related to pollinator conservation. This allowed me to explore two of my components (environmental management and pollinator conservation) in greater depth and to accomplish a variety of my learning objectives.

I sought to learn more about both contemporary theory and current methods in environmental management, and this research helped me to do both. My background reading in the academic literature informed my understanding of relevant theory in environmental management, particularly as it pertains to understanding the role of humans and the need for social science to be incorporated into conservation research and practice. I was also able to examine the relationship between theory and practice in environmental management, as I investigated the implications for conservation of viewing pollination as an ecosystem service. I also examined the responses from a variety of stakeholders (including individual citizens, those working in the agriculture industry, environmental NGOs, etc.), thereby gaining an understanding of the different perspectives on the issue and becoming able to critically evaluate the proposed policy.

In pollinator conservation, I was particularly looking to "gain an in-depth understanding of pollinator conservation policy, including the role of the public and various stakeholders in its creation.” This case study involved extensive work with comments submitted to the government from the public, and allowed me to comment on their role in influencing policy decisions. It also exposed me to the current debates in pollinator conservation policy, both academic and in the public realm, and allowed me to consider the relationship between the two and the challenges in translating conservation science to policy.

My Major Research Paper is organized in manuscript format, as it will be submitted to a peer-reviewed journal. 


\section{Acknowledgements}

Acknowledgements specific to the manuscript are listed on p. 18, but I wanted to take this opportunity to also offer my thanks to the many people who supported me throughout the MES program. First off, I would like to thank my supervisor, Sheila Colla, who consistently helped me get the most out of my MES experience, and whose insight and support have been invaluable. I would also like to thank my advisors, Gail Fraser and Martin Bunch, for seeing me through MES I and II. Thank you to Anne Bell and Emma Horrigan for providing me with the opportunity to contribute to the citizen science program at Ontario Nature last summer. Thank you also to Holly Dolan at OMAFRA, for her assistance in obtaining the comments used in my research and for answering my questions. Thank you to all my letter-writers and mentors from Trent University who helped me get here in the first place (especially Joanna Freeland, Joe Cebek, Marcel Dorken, and Sara Pieper). Thank you to all of my friends in MES, especially Lela Pacitti and Sayeh Dastgheib-Beheshti. I am also grateful for funding received from the York Graduate Scholarship, SSHRC Canada Graduate Scholarship-Master’s, and Ontario Graduate Scholarship programs. Finally, I would like to thank my

family, especially my sister and parents, and my friend Ashley Drake for their support. 


\section{Table of Contents}

Foreword / ii

Acknowledgements / iii

Table of Contents / iv

List of Tables / v

List of Figures / vi

Abstract / 1

Introduction / 2

Methods / 4

Results / 7

Discussion / 12

Literature Cited / 18

Appendices / 29

1. Complete list of sources of information referenced by commenters and displayed in

Figure 2, including description of each / 29

2. Concerns/motivations for commenting and percentages of commenters with each concern / 30 


\section{List of Tables}

Table 1. Data collected from each coded comment / 22

Table 2. Final set of coding categories for the commenter's "Motivation” / 23 


\section{List of Figures}

Figure 1. Stances of individual commenters with regards to the proposed neonicotinoid regulation / 25

Figure 2. Sources of information cited by individual commenters / 26

Figure 3. Percentages of individual commenters with each concern identified / 27

Figure 4. Percentages of commenters mentioning bees by type of bee mentioned / 28 
TITLE: Understanding public and stakeholder attitudes in pollinator conservation policy development.

AUTHORS (WITH CONTACT INFORMATION): Allison A. Nicholls ${ }^{1}$ and Sheila R. Colla*1

* Corresponding author: Sheila R. Colla

AFFILIATIONS: ${ }^{1}$ Faculty of Environmental Studies, York University, 4700 Keele Street, Toronto ON, M3J 1P3

\section{ABSTRACT:}

Pollinator conservation is a major focus of current conservation attention and policy efforts. However, an understanding of the social dimensions of pollinator conservation is urgently needed for effective action. In 2014, Ontario became the first jurisdiction in North America to propose to regulate neonicotinoid pesticides, and the proposal included a draft Pollinator Health Action Plan with additional measures to protect pollinator species. We analyzed the 972 comments submitted on the proposal by individual citizens, determining each commenter's stance, source of information (if applicable), and main concerns. We found very strong support for neonicotinoid regulation, with less than $5 \%$ opposed. We also found that the greatest concerns were for bees and pollination services, but that the diversity of pollinating species and the relative contributions of various taxa to pollination was not well understood. Government regulation of neonicotinoid pesticides and other actions to protect pollinator health clearly have the broad support and great interest of the general public, which creates a rare opportunity for conservation policy and action. We conclude that, in order to be effective, broad support will need to be translated into nuanced policy that is focussed on native pollinators and addresses the many threats those species face. 


\section{INTRODUCTION:}

The importance of the social aspects of conservation are increasingly recognized. Conservation problems often arise within socio-ecological systems, and recently multidisciplinary approaches, including disciplines and partners outside of academia, have been cited as necessary for effective conservation action (Dick et al. 2016). Specifically, many authors have argued for better inclusion of the social sciences in conservation, in order to understand the human dimensions of various environmental issues and develop effective policy and conservation management plans (e.g. Bennett et al. 2016; Blicharska et al. 2016).

An issue currently the focus of major conservation attention and policy efforts is pollinator protection. Pollinating species, which include bees, ants, wasps, butterflies, moths, flies, and beetles contribute to the pollination of plant species worldwide (Rader et al. 2016), which is important both ecologically and economically; the pollination services provided by bees alone have been valued at $\$ 3000$ per hectare (Kleijn et al. 2015). Globally, many pollinator species are declining, likely as the result of multiple threats including climate change, pesticide use, land use change, diseases, and others (IPBES 2016). Multiple jurisdictions are now considering, or have enacted, measures to protect pollinators, such as the Pollinator Partnership Action Plan, released by the United States in 2016, with the goals of promoting the health of honeybees, conserving monarch butterflies, and improving pollinator habitat (Colla \& MacIvor 2017). Pesticides, and in particular neonicotinoid pesticides, have received much attention from policymakers in recent years, especially with regards to their effects on pollinating species. In 2013, the European Union, citing negative impacts to bees, restricted the use of several widelyused neonicotinoid pesticides (Wood \& Goulson 2017). 
These actions tend to receive a good deal of media attention, but public understanding of issues surrounding pollinator declines and the ecosystem service pollinators provide is increasingly a topic of interest to researchers. For example, in Australia, Smith and Saunders (2016) found that introduced honeybees receive a disproportionate amount of media attention in online newspaper articles, where native bees and non-bee pollinators were mentioned in only a fraction of the stories. This bias may influence the public's understanding of pollinator diversity and, as a result, have real impacts on the perception of pollinator conservation needs (Smith \& Saunders 2016), while wild bees and other insect pollinators are also important contributors to crop pollination (Winfree et al. 2008; Rader et al. 2016). The perception that beekeeping is a conservation action, for example, is arguably dangerous to native pollinators and natural systems (Colla \& MacIvor 2017). Given the massive public and media interest in pollinator conservation, the diversity of pollinator species and the ecosystem services they provide, the extensive scientific literature on extent and cause of declines, and recent policy development, studies focussing on the social dimensions of pollinator conservation are urgently needed to obtain a clearer understanding of pollinator conservation as a socio-ecological system.

In 2014, Ontario became the first jurisdiction in North America to propose regulation of neonicotinoid pesticides. The regulation proposal was posted to its Environmental Registry and included a discussion paper on a proposed Pollinator Health Acton Plan, which set out two aspirational targets: an $80 \%$ reduction in the number of acres planted with neonicotinoid-treated corn and soybean seed by 2017, and lowering the over-winter honeybee mortality rate to $15 \%$ by 2020 (Government of Ontario 2016). The Environmental Registry allows the public to comment on environmental proposals within a given timeframe (Ministry of the Environment and Climate Change 2016) and is a requirement of Ontario’s Environmental Bill of Rights (EBR) (Ministry of 
Municipal Affairs and Housing 2007). When the notice (EBR Registry Number: 012-3068) was posted to the Registry and opened for comments between November 25, 2014 and January 25, 2015 (online and via an associated e-mail address), it received 52229 comments (Government of Ontario 2016). This was the highest number of comments received on a proposal since the EBR came into force in 1994 (Environmental Commissioner of Ontario). Past work has analyzed public comments on environmental matters as a way to gain insight as to the public's environmental values and stances on a given issue (e.g. Proctor 1998). Due to growing pollinator conservation concern and the consequent development of conservation strategies in jurisdictions around the world, public comments can provide much-needed insight into public attitudes and perceptions on required actions, as well as the sources of information relied upon.

In this study, public comments submitted on a draft policy proposal to the Ontario Environmental Registry were used to identify the major concerns of the public surrounding neonicotinoid regulation and pollinator conservation. In addition to determining the stances of commenters on the proposal, we determined: 1) whether concerns varied, or whether commenters were mostly motivated by the same concerns; 2) whether the public's concerns align with current pollinator conservation science; and 3) what sources of information people relied upon to support their stances.

\section{METHODS:}

Of the 52229 total comments submitted on this proposal, 50686 were submitted in writing or by phone (i.e. emailed directly, or telephone comments which were received and documented by government staff and sent to central e-mail account) and 1543 were received through the Environmental Registry (online) (Government of Ontario 2016). Approximately 47400 comments were made through seven campaigns (Ontario Ministry of Agriculture, Food, and 
Rural Affairs, personal communication), including by environmental non-governmental organizations (ENGOs) and the Ontario Beekeepers’ Association.

We obtained a copy of the comments from the Ontario Ministry of Agriculture, Food, and Rural Affairs (OMAFRA). These included all unique comments submitted by individuals, and a sample of those sent through campaigns. Personal information (including direct and indirect identifier information, such as postal codes or other information which could reveal a person's identity) had been redacted.

The comments had already been divided into those that were submitted via the Environmental Registry (will be referred to as EBR comments) and those that were sent to the email address associated with the proposal (E-mails); upon receiving the comments, we further subdivided the two groups into Individual (unique) and other comments, which included the campaign (form letter) comments, as well as letters sent on behalf of organizations, and noncomments (e.g. gibberish, requests for information, etc.). After sorting, we determined that 311 individual (i.e. non-campaign) e-mails were received and 661 individual comments were submitted online.

All 972 individual comments were then coded. For each comment, we recorded: a) the commenter's stance on the proposal (advocating more/less/the same amount of neonicotinoid regulation as proposed) and b) if applicable, their source of information to support that stance (scientific article, popular media (newspaper, website, campaign, etc.), government reports, anecdotal evidence, general references to "science", past situations, situations elsewhere in the world, etc.) (see Table 1). We also recorded: c) where identified in the comment, if the individual was a farmer or a beekeeper or both, as these were two major groups of commenters we 
identified at the outset. If the individual identified themselves as belonging to another group or profession, we recorded this information as well (see Table 1).

We then coded the commenter's motivations, i.e. what issues they cited as being of concern. We analyzed the comments using the directed content analysis approach outlined by Hsieh and Shannon (2005). We identified initial codes from the government summary of the comments, which identified a number of common concerns, as well as from the subset of comments that were available online, and from browsing of all comments during initial sorting. These initial codes included: references to pollination services, concern for human health (with regards to chemicals contained in the pesticides), concerns regarding bee species, concern for other (non-human and non-bee) species, provisions already made to protect pollinators, moral arguments, concerns about industry influence on the process, references to Ontario’s leadership on the issue, and economic concerns (see Table 2).

In the government summary of the responses on the Environmental Registry (Government of Ontario 2016), a number of additional categories are listed, including recommendations regarding pollinator habitat, education and outreach efforts, and so on. As the present research question specifically pertains to commenters' motivations for commenting (i.e., the main concerns that drove them to submit a comment, as inferred from the comment itself), we have not included these categories.

We gave each issue identified (initial codes stated above, and found in Table 2) a column in the MS Excel spreadsheet used to record results, and we copied and pasted the relevant text from each comment into the spreadsheet. We also recorded results quantitatively (1/0) in a second spreadsheet. If we identified subthemes within a particular issue, the issue was subdivided into new coding categories, and we re-analyzed all comments assigned to the 
category before subdivision to ensure they were correctly coded. We read each comment twice, with coding occurring on the second reading (per Center for Evaluation and Research 2012). We gave a new code to any comment that did not fit into one of the predetermined codes (see Table 2 for final list of codes).

\section{RESULTS:}

\section{$\underline{\text { Stance: }}$}

Previous reports indicated that $97 \%$ of all comments were in favour of the proposal (David Suzuki Foundation 2015). Regarding the proposed neonicotinoid regulations specifically, we found that support among individuals submitting comments outside of a campaign was also very high: over 95\% of those who took an explicit stance were in favour of regulating neonicotinoids; many were in favour of more regulation than what was proposed in the draft policy (49.5\% of those who took an explicit stance, or $43.3 \%$ of all individual commenters) (Figure 1). Of the 972 individual comments that were coded, 121 (12.4\%) did not express an explicit stance on the proposed neonicotinoid regulation. Only 3.9\% of commenters (or $4.5 \%$ of those who took an explicit stance) wanted less regulation.

Sources of Information:

While most commenters did not provide any source of information, among those who did there were several clear trends. Of the 972 comments, 94 (9.7\%) of them relied on anecdotal evidence to support their stances; this included personal experience or observations (for example, on trends in bee health or personal health concerns) and conversations with (perceived) experts, such as local beekeepers. Anecdotal evidence comprised one-third of all evidence given by commenters (Figure 2). 
The second-largest category was general references to "science" (including "scientific evidence," "scientific research,” "research,” etc.; see Appendix 1 for full descriptions). This is distinct from comments that referenced specific scientific studies, as the commenter indicates that "science" is on his/her side without demonstrating that he/she has actually read primary or even secondary scientific sources him-/herself. A total of 50 commenters (9.6\%) referred to "science"/"research" (etc.). Commenters could provide multiple sources of information (e.g. a book and a website). References to "science" represent $17.7 \%$ of all sources of information provided.

The third-largest category was the "Elsewhere" category, which included references to case studies outside of Ontario. In total, 41 commenters (4.2\%) referred to experiences elsewhere; these references represent $14.5 \%$ of all sources of information provided by commenters. Many people mentioned the 2013 neonicotinoid moratorium by the European Union (often referred to as a "ban"). Another case study cited by multiple commenters was China, said to be relying on hand-pollination by humans after the widespread deaths of pollinators. Both were used to support the stance that neonicotinoids should be regulated and/or banned completely.

One sub-theme that occurred across multiple source categories was the historical case of the pesticide DDT (referenced by $2.4 \%$ of those who provided any source). Some commenters referenced Rachel Carson's book on the topic, Silent Spring, or neonicotinoids being thousands of times more toxic than DDT. However, several commenters cited their own past experiences with DDT, in particular expressing that they themselves had noticed bird declines in past and that influenced their decision to comment on this proposal (and presumably, their stances on pesticides in general). 


\section{Motivations/Main Concerns:}

Of the 972 individual commenters, 187 (19.2\%) simply stated their stances on the proposal, without identifying what their concerns or motivations for commenting were. Since their concerns were unknown, these comments have been excluded in reporting percentages.

Comments could include multiple concerns. The top two concerns, each cited by over $50 \%$ of commenters who identified any concerns were for bees and pollination services (Figure 3).

Bees were mentioned by $61 \%$ of commenters who cited concerns, and $52.7 \%$ of those mentioning bees also mentioned pollination services. Of those comments that mentioned bees, 73.5\% simply referred to "bees", without specifying what type or species (Figure 4).

Additionally, 21.6\% referred to honeybees; $8.4 \%$ explicitly stated honeybees, and an additional 13.2\% referred to "bees" but gave other clues that they meant honeybees (e.g. references to honey, beekeepers, and/or colony collapse disorder). Bumblebees were mentioned by $1.2 \%$ of commenters who mentioned bees, and the final 3.8\% included all other bee references (commenters usually referring to non-specific "native” or "wild” bees). There were some comments that referred to multiple types of bees; in those cases, it was always honeybees and something else. Additionally, people reported both deaths in their own hives or those of a beekeeper acquaintance, as well as noticing declines in bees (e.g. in their gardens).

A sub-theme within the Bee category was bees as environmental indicators; commenters referred to bees as indicators of a greater problem, and multiple commenters also referenced bees as "canaries in the coal mine." Many commenters discussed bees as "our bees," displaying a sense of ownership; another common theme was that without bees nothing at all will grow. 
Pollination services were cited as being of concern by $53.2 \%$ of commenters with any concern. Those who did not mention bees specifically almost always mentioned "pollinators."

Of the commenters who did not mention either bees or pollination, there were no obvious trends, although many mentioned general environmental concerns. In the e-mails, other concerns of this group included economic concerns and general distrust of industry; for both e-mails and EBR submissions, there were also a few comments across the other concern categories.

Other (non-human and non-bee) species were mentioned by 23.3\% of commenters; this number also does not include comments that only referred to "pollinators" (which comprised $23.7 \%$ of the comments), as these were coded under Pollination Services and it is impossible to distinguish between those thinking of bee pollinators versus other species. In total, $13.4 \%$ of commenters referred to pollinating species and qualified that reference in some way, including "wild,” “natural,” or “native” pollinators, or specifically referred to butterflies (including monarch butterflies specifically), moths, insects, birds, or bats. Other species of concern for these commenters included species identified as dependent on insects, especially birds, as well as insect-eating fish and amphibians; trees; aquatic organisms and earthworms; and some also included general references to all life, animals, or the food chain. Finally, 9.9\% of commenters referred to other species without mentioning "pollinators"; however, in this group, concerns were typically for the same species as noted above (insectivorous birds; butterflies, earthworms, fish, etc.).

General environmental concerns were expressed by 33.4\% of commenters with any concern; these include general references to ecology, ecosystems, the planet, Earth, etc.

Over $15 \%$ of comments with any concerns expressed either concerns regarding industry influence on the policy creation process (7.3\%) or general distrust of industry (8.2\%). 
Other major concerns included human health concerns (13.5\%; mostly general concerns and not specific illnesses), economic concerns (12.9\%), concerns for future generations (7.8\%), and references to Ontario's leadership on the issue (8.8\%; including both pride in Ontario being first in North America to (propose to) regulate neonicotinoids and calls by commenters from outside of Ontario for the province to act in order to lead their own governments to similar action).

There were also several key trends in arguments against the regulation. These commenters (38 out of 972) consistently cited economic concerns, though often also expressing concern for the environment. Six commenters of the 38 in this group also had concerns about the influence of NGOs on the policy creation process that were not found in any comments supporting the proposal. Additionally, and in greater numbers, these commenters expressed concerns regarding the beekeeping industry (31.6\% of those wanting less regulation, or 12 out of 38 individuals). Common arguments in this area included: that the beekeeping industry is not shouldering any of the responsibility for bee deaths, even though poor hive management practices by some beekeepers may be a major cause; that provisions have already been made by those in the agriculture industry to cut down on harm from neonicotinoids (in particular, the recent introduction of fluency agent); that more time and/or research is needed; that emphasis has unfairly been placed on those in the agriculture industry or on pesticides themselves as the cause of bee deaths. This group of commenters arguing against the proposed neonicotinoid regulation included farmers as well as those working in agriculture in other capacities, but working directly with neonicotinoids (including seed dealers, agronomists, agri-business owners, crop advisors, grain buyers, and “agriculture industry employees”). 
Interestingly, of the farmers who commented (and self-identified as farmers), there was not consensus on the issue of neonicotinoid regulation, as farmers were found on either side of the debate; of 47 identified farmers, 18 (39.3\%) wanted less neonicotinoid regulation than proposed, while 15 (32.0\%) supported the regulation as proposed, and 13 (27.7\%) wanted more regulation (one took no explicit stance). Half of the farmers in support of the proposal identified themselves as organic farmers, so were not currently employing neonicotinoid pesticides in their operations.

\section{DISCUSSION:}

It is crucial that environmental policy be informed by science in order to be effective, and avoid oversimplifying complex socio-ecological issues (Bradshaw \& Borchers 2000). Many recent studies have documented negative impacts of neonicotinoid pesticides on wildlife, including bees (e.g. Gibbons et al. 2015; Wood \& Goulson 2017). Government regulation of neonicotinoid pesticides and other actions to protect pollinator health clearly have the broad support and great interest of the general public, which creates a rare opportunity for ambitious conservation policy and action. However, a more nuanced approach to pollinator health is required than was proposed in this case study, or understood by much of the general public.

When asked for their input on regulating neonicotinoids and creating a wider plan to promote pollinator health, the public's overwhelming concerns were for the health of bees specifically and the preservation of pollination services more generally (Figure 3). However, this concern for pollination services does not align with the major species of concern. Many commenters argued that without bees, there would be "no food", while previous work has shown that non-bee pollinating insects such as ants, wasps, butterflies, moths, flies, and beetles contribute approximately equally to global pollination services as do bees (Rader et al. 2016). 
Additionally, only 35\% of global crop production volume is dependent on animal pollinators, and staple crops like wheat and corn are not (Klein et al. 2007).

While many members of the public appear to have only a basic understanding of the pollination process, that is not as concerning from a conservation standpoint as the poor understanding of bee species diversity that the comments revealed. In Australia, honeybees dominate the public conversation surrounding pollinators and pollinator conservation (Smith \& Saunders 2016), and clearly this phenomenon is widespread. Most commenters here who expressed concerns for bees did not mention specific taxa or species, and those that did usually referred to honeybees (both directly and indirectly) (Figure 4). Thus, while the public showed great concern for bees and pollination, the comments include an overemphasis on honeybees, which is also focussed on in the proposed policy itself. However, the honeybee (Apis mellifera) is a managed, non-native bee species in North America (Whitfield et al. 2006). Additionally, wild pollinators have been found to be more effective agricultural crop pollinators than honeybees (Garibaldi et al. 2013). There is also evidence that honeybees themselves can cause problems for native pollinators, by competing for resources (Goulson \& Sparrow 2009) or spreading diseases from managed hives to wild bees (Singh et al. 2010). Thus, a focus on conserving honeybees in public conversation of environmental policy is misplaced, and potentially even harmful to native pollinators and natural ecosystem services (Colla \& MacIvor 2017).

While neonicotinoid pesticides are clearly a threat to bees (Wood \& Goulson 2017), it is important that actions to regulate them are taken as part of a multi-faceted conservation strategy that acknowledges the many anthropogenic threats faced by bees and other pollinators. Many commenters in this study cited bee declines and pointed to neonicotinoids as the cause. While 
neonicotinoids have been shown to have negative effects on honeybees at field-realistic exposure levels (Tsvetkov et al. 2017), as well as negative reproductive effects on wild bees (Baron et al. 2017; Woodcock et al. 2017), they are not the only threat to bees or to other pollinators. Threats to bees differ between species, and besides pesticides, can include pathogens from managed bees, climate change, and land-use change (Cariveau \& Winfree 2015); interactions of other commonly-applied agricultural chemicals with neonicotinoids can also worsen their impacts on honeybees (Tsvetkov et al. 2017).

Clearly, there is a need to shift the public conversation surrounding pollinator health to focus on multi-faceted strategies that will aid native pollinators, especially those assessed to be at risk of extinction. For example, habitat creation is important, and previous work has demonstrated that humans can manage urban and suburban areas to improve pollination services (e.g. by bumblebees; see Jha \& Kremen 2013). In Ontario, a third aspirational target was added to the Pollinator Health Action Plan, which was created in 2016 following an additional public and stakeholder consultation period: "To restore, enhance and protect 1 million acres of pollinator habitat in Ontario” (OMAFRA 2016). The policy is general, but an introductory section highlights the importance of native pollinators (OMAFRA 2016). While it remains to be seen if the varying habitat needs of different pollinator species will be incorporated into the planned actions, the addition of habitat protection as a major aspirational target has the potential to greatly expand the scope of pollinator protection.

This study also demonstrates the importance of building bridges with stakeholders for policy development. The proposal was contentious among the agriculture community, and Ontario's Minister of Environment and Climate Change eventually apologized to the agriculture community for inadequate effort to build bridges (in November 2016 at the annual meeting of 
the Ontario Federation of Agriculture) (Greig 2016). Individual commenters gave insight as to the sentiments of those who were opposed to the proposed policy (38 out of 972 total commenters; Figure 1), and generally identified themselves as people who worked directly with neonicotinoids, including some farmers, seed dealers, agronomists, crop advisors, and others in the agriculture industry. While many expressed concern for the environment and/or bees, they felt that the beekeeping industry itself was not under any scrutiny for the reported overwintering deaths, as opposed to the situation with those in the agriculture industry. This is consistent with recent studies that have also pointed to multiple factors in honeybee declines, especially Varroa mites spread through trade and movement of honeybee colonies (Staveley et al. 2013; Moritz \& Erler 2016; Wilfert et al. 2016). This concern is also interesting because, indirectly, it is a reflection of the proposal's overemphasis on honeybees as the reason for limiting neonicotinoid use. There were also concerns that recent provisions had been made (i.e. fluency agent) to reduce harm, but results from this change were not yet understood and the proposed policy did not take this change into consideration. Despite their opposition to the regulation proposed, these commenters did not dispute that pollination was important, even that neonicotinoids may cause environmental harm. Thus, changing the focus to native pollinators and working harder with agricultural stakeholders could potentially garner more support for actions to regulate neonicotinoids and protect pollinators (and other wildlife).

This again shows the importance of creating a multi-faceted pollinator health strategy, so as not to alienate important stakeholders. One commenter wrote that "the proposal, based on thin and narrowly selected information, only addresses a single agronomic actor - as if it were the main solution to the complex issues of variable bee mortality. In so doing the proposal has polarised rural groups and further driven the Ontario geo-political wedge along an urban and 
rural fault line” (Comment \#180137). There was a clear neonicotinoid user/non-user divide in support for the policy, but whether this divide is also along urban/rural lines cannot be determined without geographic data, which most of the comments lacked. While most commenters favoured neonicotinoid regulation, many supporting even greater regulation than proposed, those most immediately affected by the regulations had strong, and mostly consistent, opinions, and the response of policymakers to those concerns is also an important part of the process. It would be useful to know if most of the comments came from people in urban centres or whether support was spread throughout both urban and rural areas.

Besides the opportunity for the public to provide written comments, the Ministry held a variety of meetings to which "[a]gricultural organizations, other key organizations such as environmental organizations, seed trade industry, the pesticide sector, and all members of the public were invited" (Government of Ontario 2016). The present work did not consider these meetings, as the goal of this study was to better understand public motivation and stance on the neonicotinoid reduction policy. In order to investigate how public feedback actually influenced the regulation and policy creation process, a stakeholder analysis could be conducted. This would involve the identification of stakeholders and the relationships between them (Reed et al. 2009), which is beyond the scope of the work done here, but would be a useful next step.

It would be especially useful to better understand the role of the beekeeping industry in the policy decision-making process. While the individual comments analyzed here can provide insight into public thought regarding neonicotinoid pesticides and pollinator health, the vast majority of comments received on the proposal came through campaigns, including one by the Ontario Beekeepers’ Association and others by (especially environmental) non-governmental organizations (NGOs), both of which made form letters available for submission by the public. It 
is unknown how many letters were submitted by each campaign, as only a subset were redacted and included in the comments received for this research. If obtained, that information could also contribute to a stakeholder analysis process, and provide insight as to what extent the focus on honeybees may have been influenced by the beekeeping industry itself.

Individual commenters tended to rely on personal experience as a source of information, but because so many comments came through campaigns, environmental NGOs were likely the main source of information for the public. Further work could examine how the public becomes aware of these campaigns, and specifically how often people seek out campaigns when they want to comment on an issue, versus how much awareness of the issue is generated by the campaigns themselves.

Finally, the role of pesticide industry lobbying in the creation of pollinator conservation policy should also be further investigated. In addition to existential concerns related to the loss of pollinators, a major reason for the public's support for neonicotinoid regulation was the perception that it was being imposed on industry, rather than individuals. The government was seen as holding industry accountable and commenters supported this role, not trusting the pesticide industry to self-regulate. Commenters in favour of the proposal expressed the desire for the government to "stay strong" in the face of industry pushback, suggesting a concern that the government would give in to lobbying efforts.

\section{Conclusion}

Policymakers should translate broad public support for neonicotinoid regulation and pollinator protection into policy that is focussed on native pollinators and addresses the many threats those species face. 


\section{ACKNOWLEDGEMENTS:}

We would like to thank the Ontario Ministry of Agriculture, Food, and Rural Affairs

(OMAFRA) for provision of the comments and for relevant correspondence; J. Pittman and R.

Nalepa for helpful comments on early study design and early drafts of the manuscript; and M.

Damian-Flores and J. Nicholls for assistance in the coding process.

\section{LITERATURE CITED:}

Baron GL, Raine NE, Brown MJF. 2017. General and species-specific impacts of a neonicotinoid insecticide on the ovary development and feeding of wild bumblebee queens. Proceedings of the Royal Society B 284: 20170123.

Bennett NJ, et al. 2016. Conservation social science: Understanding and integrating human dimensions to improve conservation. Biological Conservation 205: 93-108.

Blicharska M, Orlikowska EH, Roberge J-M, Grodzinska-Jurczak M. 2016. Contribution of social science to large scale biodiversity conservation: A review of research about the Natura 2000 network. Biological Conservation 199: 110-122.

Bradshaw GA, Borchers JG. 2000. Uncertainty as information: narrowing the science-policy gap. Conservation Ecology 4: 7-14.

Cariveau DP, Winfree R. 2015. Causes of variation in wild bee responses to anthropogenic drivers. Current Opinion in Insect Science 10: 104-109.

Center for Evaluation and Research - Tobacco Control Evaluation Center. 2012. Tips \& Tools \#18: Coding Qualitative Data. Tobacco Control Evaluation Center at University of California, Davis, Davis, California, United States. Available from http://programeval.ucdavis.edu/analysisreporting/documents/CodingQualitativeData.pdf (accessed July 2017).

Colla SR, MacIvor JS. 2017. Questioning public perception, conservation policy, and recovery actions for honeybees in North America. Conservation Biology DOI: 10.1111/cobi.12839.

David Suzuki Foundation. 2015. Ontario supports pollinator health. Vancouver, Canada. Available from http://www.davidsuzuki.org/publications/finding-solutions/2015/spring/ontariosupports-pollinator-health/ (accessed July 2017).

Dick M, Rous AM, Nguyen VM, Cooke SJ. 2016. Necessary but challenging: Multiple disciplinary approaches to solving conservation problems. FACETS 1: 67-82. 
Garibaldi LA, et al. 2013. Wild Pollinators Enhance Fruit Set of Crops Regardless of Honey Bee Abundance. Science 339: 1608-1611.

Gibbons D, Morrissey C, Mineau P. 2015. A review of the direct and indirect effects of neonicotinoids and fipronil on vertebrate wildlife. Environmental Science and Pollution Research 22: 103-118.

Goulson D, Sparrow KR. 2009. Evidence for competition between honeybees and bumblebees; effects on bumblebee worker size. Journal of Insect Conservation 13: 177-181.

Government of Ontario. 2016. Regulation Decision Notice: Title: Pollinator Health: A Proposal for Enhancing Pollinator Health and Reducing the Use of Neonicotinoid Pesticides in Ontario. Toronto, Canada. Available from https:/www.ebr.gov.on.ca/ERS-WEBExternal/displaynoticecontent.do?noticeId=MTIzOTE5\&statusId=MTkyMjcy (accessed July 2017).

Greig J. 2016. Ontario environment minister reaches out to farmers. AGCanada, Winnipeg, Canada. Available from https://www.agcanada.com/daily/greig-ontario-environment-ministerreaches-out-to-farmers (accessed July 2017).

Hsieh H-F, Shannon SE. 2005. Three Approaches to Qualitative Content Analysis. Qualitative Health Research 15: 1277-1288.

IPBES. 2016. Summary for policymakers of the assessment report of the Intergovernmental Science-Policy Platform on Biodiversity and Ecosystem Services on pollinators, pollination and food production. Potts SG, et al. (eds.). Secretariat of the Intergovernmental Science-Policy Platform on Biodiversity and Ecosystem Services, Bonn, Germany. Available from http://www.ipbes.net/sites/default/files/downloads/pdf/spm_deliverable_3a_pollination_2017022 2.pdf (accessed July 2017).

Jha S, Kremen C. 2013. Resource diversity and landscape-level homogeneity drive native bee foraging. Proceedings of the National Academy of Sciences of the United States of America 110: 555-558.

Kleijn D, et al. 2015. Delivery of crop pollination services is an insufficient argument for wild pollinator conservation. Nature Communications 6: 7414.

Klein A-M, Vaissière BE, Cane JH, Steffan-Dewenter I, Cunningham SA, Kremen C, Tscharntke T. 2007. Importance of pollinators in changing landscapes for world crops. Proceedings of the Royal Society B 274: 303-313.

Ministry of Municipal Affairs and Housing. 2007. EBR Environmental Registry. Toronto, Canada. Available from http://www.mah.gov.on.ca/Page1691.aspx (accessed July 2017).

Ministry of the Environment and Climate Change. 2016. Discussion Guide to Review of 
Ontario’s Environmental Bill of Rights and Regulations and Consideration of Ontarians' Environmental Rights. Toronto, Canada. Available from http://www.downloads.ene.gov.on.ca/envision/env_reg/er/documents/2016/0128002\%20guide.pdf (accessed July 2017).

Moritz RFA, Erler S. 2016. Lost colonies found in a data mine: Global honey trade but not pests or pesticides as a major cause of regional honeybee colony declines. Agriculture, Ecosystems \& Environment 216: 44-50.

OMAFRA (Ontario Ministry of Agriculture, Food, and Rural Affairs). 2016. Ontario’s Pollinator Health Action Plan. Toronto, Canada. Available from http://www.omafra.gov.on.ca/english/pollinator/action_plan.pdf (accessed July 2017).

Proctor JD. 1998. Environmental Values and Popular Conflict over Environmental Management: A Comparative Analysis of Public Comments on the Clinton Forest Plan. Environmental Management 22: 347-358.

Rader R, et al. 2016. Non-bee insects are important contributors to global crop pollination. Proceedings of the National Academy of Sciences of the United States of America 113: 146-151.

Reed MS, Graves A, Dandy N, Posthumus H, Hubacek K, Morris J, Prell C, Quinn CH, Stringer LC. 2009. Who's in and why? A typology of stakeholder analysis methods for natural resource management. Journal of Environmental Management 90: 1933-1949.

Singh R, Levitt AL, Rajotte EG, Holmes EC, Ostiguy N, vanEngelsdorp D, Lipkin WI, dePamphilis CW, Toth AL, Cox-Foster DL. 2010. RNA Viruses in Hymenopteran Pollinators: Evidence of Inter-Taxa Virus Transmission via Pollen and Potential Impact on Non-Apis Hymenopteran Species. PLoS ONE (e14357) DOI:10.1371/journal.pone.0014357.

Smith TJ, Saunders ME. 2016. Honey bees: the queens of mass media, despite minority rule among insect pollinators. Insect Conservation and Diversity 9: 384-390.

Staveley JP, Law SA, Fairbrother A, Menzie CA. 2013. A Causal Analysis of Observed Declines in Managed Honey Bees (Apis mellifera). Human and Ecological Risk Assessment: An International Journal 20: 566-591.

Tsvetkov N, Samson-Robert O, Sood K, Patel HS, Malena DA, Gajiwala PH, Maciukiewicz P, Fournier V, Zayed A. 2017. Chronic exposure to neonicotinoids reduces honey bee health near corn crops. Science 356: 1395-1397.

Whitfield CW, Behura SK, Berlocher SH, Clark AG, Johnston JS, Sheppard WS, Smith DR, Suarez AV, Weaver D, Tsutsui ND. 2006. Thrice Out of Africa: Ancient and Recent Expansions of the Honey Bee, Apis mellifera. Science 314: 642-645. 
Wilfert L, Long G, Leggett HC, Schmid-Hempel P, Butlin R, Martin SJM, Boots M. 2016. Deformed wing virus is a recent global epidemic in honeybees driven by Varroa mites. Science 351: 594-597.

Winfree R, Williams NM, Gaines H, Ascher JH, Kremen C. 2008. Wild bee pollinators provide the majority of crop visitation across land-use gradients in New Jersey and Pennsylvania, USA. Journal of Applied Ecology 45: 793-802.

Wood TJ, Goulson D. 2017. The environmental risks of neonicotinoid pesticides: a review of the evidence post 2013. Environmental Science and Pollution Research DOI 10.1007/s11356-0179240-x.

Woodcock BA, et al. 2017. Country-specific effects of neonicotinoid pesticides on honey bees and wild bees. Science 356: 1393-1395. 
Table 1: Data collected from each coded comment:

\begin{tabular}{|l|l|l|l|l|}
\hline Comment \# & Format & Identity & Stance & $\begin{array}{l}\text { Source of Information } \\
\text { (see Appendix 1 for full descriptions) }\end{array}$ \\
\hline $\begin{array}{l}\text { Unique } \\
\text { number ID } \\
\text { assigned to } \\
\text { each } \\
\text { comment by } \\
\text { the Ontario } \\
\text { Ministry of } \\
\text { Agriculture, } \\
\text { Food, and } \\
\text { Rural } \\
\text { Affairs } \\
\text { (OMAFRA) }\end{array}$ & E-mail & $\begin{array}{l}\text { Farmer, } \\
\text { Beekeeper, } \\
\text { Both, } \\
\text { Other } \\
\text { (specify) }\end{array}$ & $\begin{array}{l}\text { More } \\
\text { regulation, } \\
\text { Less } \\
\text { regulation, } \\
\text { Same } \\
\text { amount of } \\
\text { regulation } \\
\text { as }\end{array}$ & $\begin{array}{l}\text { Newspaper; Website; Campaign; } \\
\text { Scientific article; Anecdotal; Quotation; } \\
\text { General references to "science," "scientific } \\
\text { evidence/studies/research," etc.; Book; } \\
\text { Past Cases (e.g. DDT); Elsewhere (e.g. } \\
\text { proposed }\end{array}$ \\
& & & $\begin{array}{l}\text { Personal Study (undertaken by commenter, } \\
\text { local group); } \\
\text { Government/Government Agency Reports; } \\
\text { Film; NGO (e.g. IUCN, Xerces); Other }\end{array}$ \\
& & & \\
& & & \\
\hline
\end{tabular}


Table 2: Final set of coding categories for the commenter's "Motivation”; comments could be coded under multiple categories. Each category contains a description of the category and an example of one of the comments coded in it. (continued on next page):

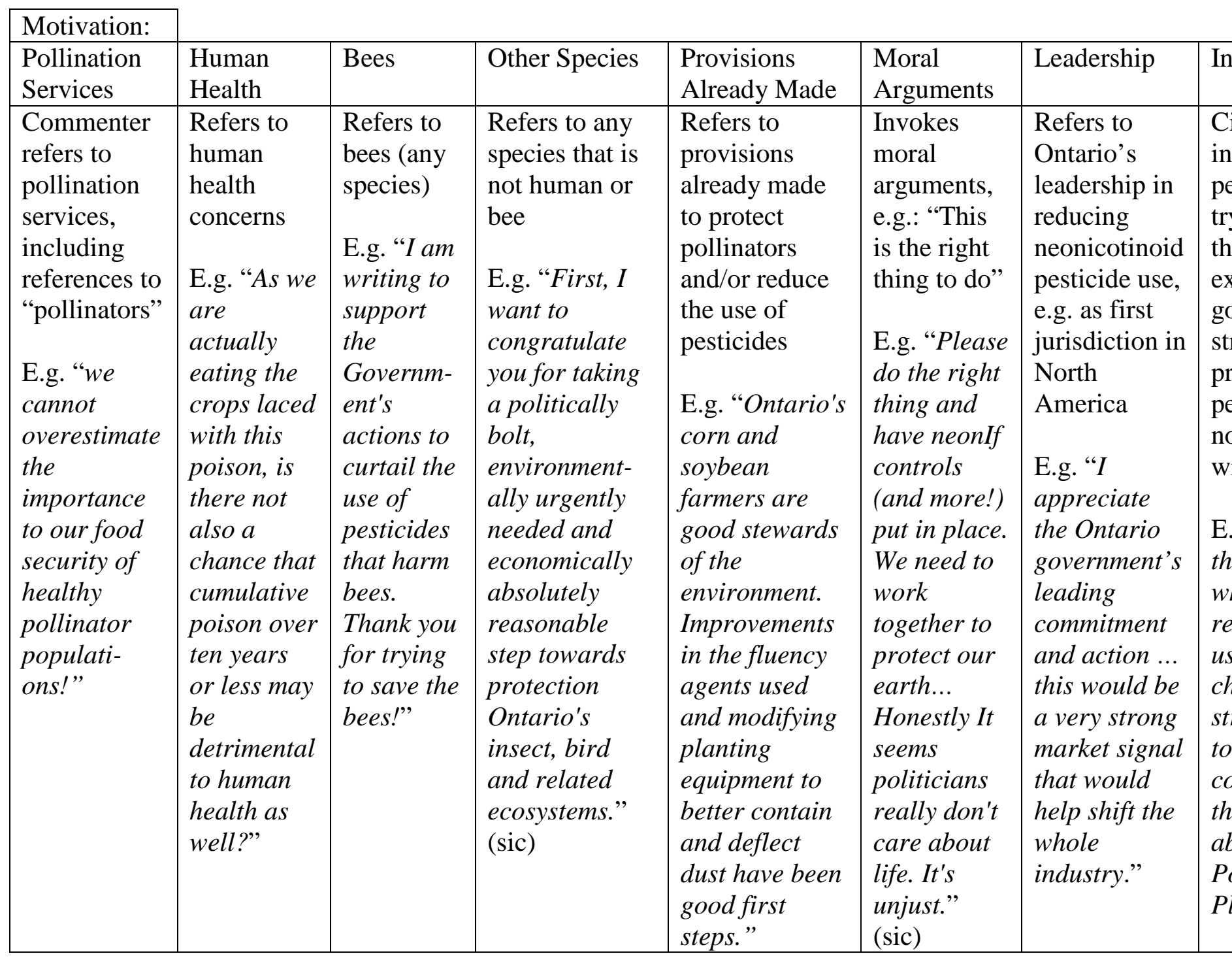


Table 2 (continued from previous page):

\begin{tabular}{|c|c|c|c|c|c|c|}
\hline $\begin{array}{l}\text { otivation } \\
\text { ont.'d) }\end{array}$ & & & & & & \\
\hline Economic & \begin{tabular}{|l|} 
General \\
Environment \\
al Concerns
\end{tabular} & \begin{tabular}{|l|} 
Time/ \\
Research
\end{tabular} & $\begin{array}{l}\text { NGO } \\
\text { Influence }\end{array}$ & $\begin{array}{l}\text { Beekeeping } \\
\text { Industry } \\
\text { Concerns }\end{array}$ & $\begin{array}{l}\text { General } \\
\text { Industry } \\
\text { Distrust }\end{array}$ & Not Practical \\
\hline $\begin{array}{l}\text { Refers to } \\
\text { how the } \\
\text { proposal } \\
\text { will affect } \\
\text { the } \\
\text { economy } \\
\text { E.g. } \\
\text { “...could } \\
\text { and } \\
\text { probably } \\
\text { will have } \\
\text { serious } \\
\text { financial } \\
\text { consequenc } \\
\text { es for Ag in } \\
\text { Ontario one } \\
\text { of the main } \\
\text { drivers of } \\
\text { the } \\
\text { economy!” }\end{array}$ & $\begin{array}{l}\text { Cites } \\
\text { concerns for } \\
\text { the general } \\
\text { environment, } \\
\text { including } \\
\text { water or air } \\
\text { pollution, or } \\
\text { general } \\
\text { references to } \\
\text { the planet, } \\
\text { Earth, nature, } \\
\text { ecology, } \\
\text { environment, } \\
\text { etc. } \\
\text { E.g. “... I am } \\
\text { deeply } \\
\text { troubled by } \\
\text { the } \\
\text { decreasing } \\
\text { health and } \\
\text { vitality of our } \\
\text { natural } \\
\text { environ- } \\
\text { ment.” }\end{array}$ & $\begin{array}{l}\text { Indicates } \\
\text { that more } \\
\text { time } \\
\text { and/or } \\
\text { research } \\
\text { are needed } \\
\text { before the } \\
\text { issue is } \\
\text { fully } \\
\text { underst- } \\
\text { ood } \\
\text { E.g. } \\
\text { "Maybe } \\
\text { we need to } \\
\text {...wait for } \\
\text { the } \\
\text { scientific } \\
\text { evaluation } \\
\text { of this } \\
\text { situation } \\
\text { to report } \\
\text { on their } \\
\text { findings." }\end{array}$ & $\begin{array}{l}\text { Cites concerns } \\
\text { that non- } \\
\text { governmental } \\
\text { organizations } \\
\text { are trying to } \\
\text { influence the } \\
\text { policy creation } \\
\text { process } \\
\text { E.g. "There is } \\
\text { documented } \\
\text { support that } \\
\text { the political } \\
\text { views of a very } \\
\text { slim few } \\
\text { individuals } \\
\text { from "green" } \\
\text { environmental } \\
\text { organizations } \\
\text { has influenced } \\
\text { a government } \\
\text { that is willing } \\
\text { to govern } \\
\text { "from the } \\
\text { activist } \\
\text { centre"..." }\end{array}$ & $\begin{array}{l}\text { Cites concerns } \\
\text { with the } \\
\text { beekeeping } \\
\text { industry (inc. } \\
\text { influence on the } \\
\text { process and fault } \\
\text { of beekeepers in } \\
\text { causing bee } \\
\text { deaths) } \\
\text { E.g. "If we had } \\
\text { less } \\
\text { conventional } \\
\text { neonicotinoid } \\
\text { use in Ontario, } \\
\text { we would still } \\
\text { have bee colony } \\
\text { collapse } \\
\text { disorder, } \\
\text { because many } \\
\text { bee-keepers are } \\
\text { NOT competent } \\
\text { to manage their } \\
\text { hives.” }\end{array}$ & $\begin{array}{l}\text { Expresses } \\
\text { anti- } \\
\text { (pesticide) } \\
\text { industry } \\
\text { sentiment, } \\
\text { without } \\
\text { including } \\
\text { concerns over } \\
\text { industry } \\
\text { influence on } \\
\text { the process } \\
\text { E.g. “The } \\
\text { pesticide } \\
\text { industry has } \\
\text { refused to } \\
\text { regulate itself } \\
\text { and confine } \\
\text { the use of this } \\
\text { powerful } \\
\text { class of } \\
\text { pesticides to } \\
\text { occasions of } \\
\text { demonstrable } \\
\text { need.” }\end{array}$ & $\begin{array}{l}\text { Cites } \\
\text { concerns that } \\
\text { the proposal } \\
\text { as presented } \\
\text { is not } \\
\text { practical for } \\
\text { implementa- } \\
\text { tion } \\
\text { E.g. "But I'm } \\
\text { concerned } \\
\text { that it is too } \\
\text { cumbersome } \\
\text { and relies too } \\
\text { much on } \\
\text { farmer } \\
\text { training and } \\
\text { practice." }\end{array}$ \\
\hline
\end{tabular}




\section{Stances of Individual Commenters}

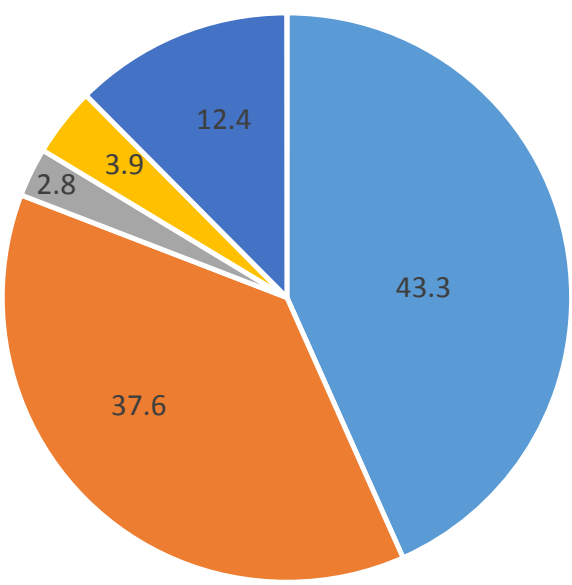

- More $\square$ Same $\quad$ More/Same $\|$ Less - No Explicit Stance

Figure 1: Stances of individual commenters with regards to the proposed neonicotinoid regulation (e-mails and online submission combined, $n=972$ ). "More/Same" refers to commenters who indicated their support for either a ban or reduction in neonicotinoid usage, with no stated preference between the two. 


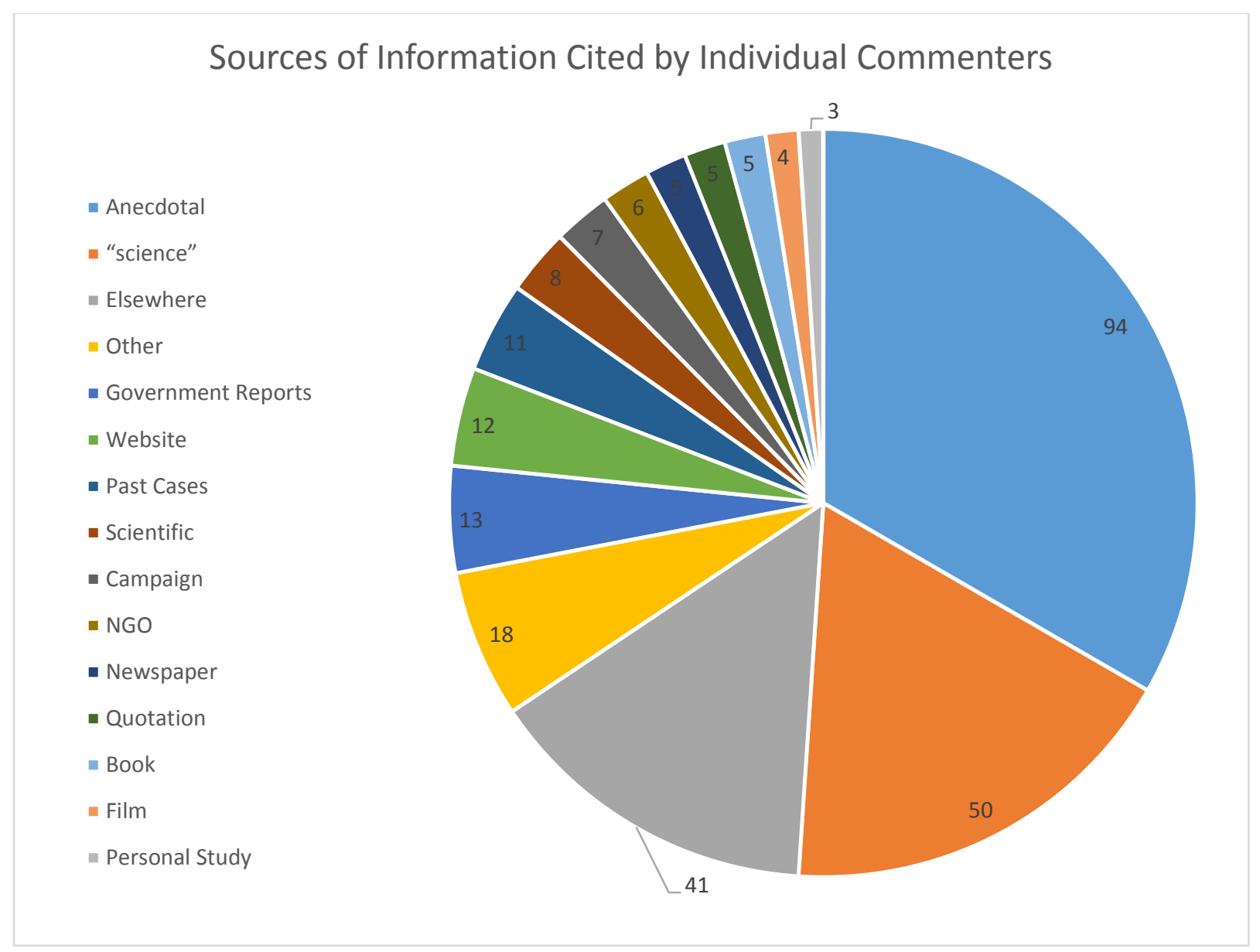

Figure 2: Sources of information cited by individual commenters. For full description of each type, see Appendix 1. 


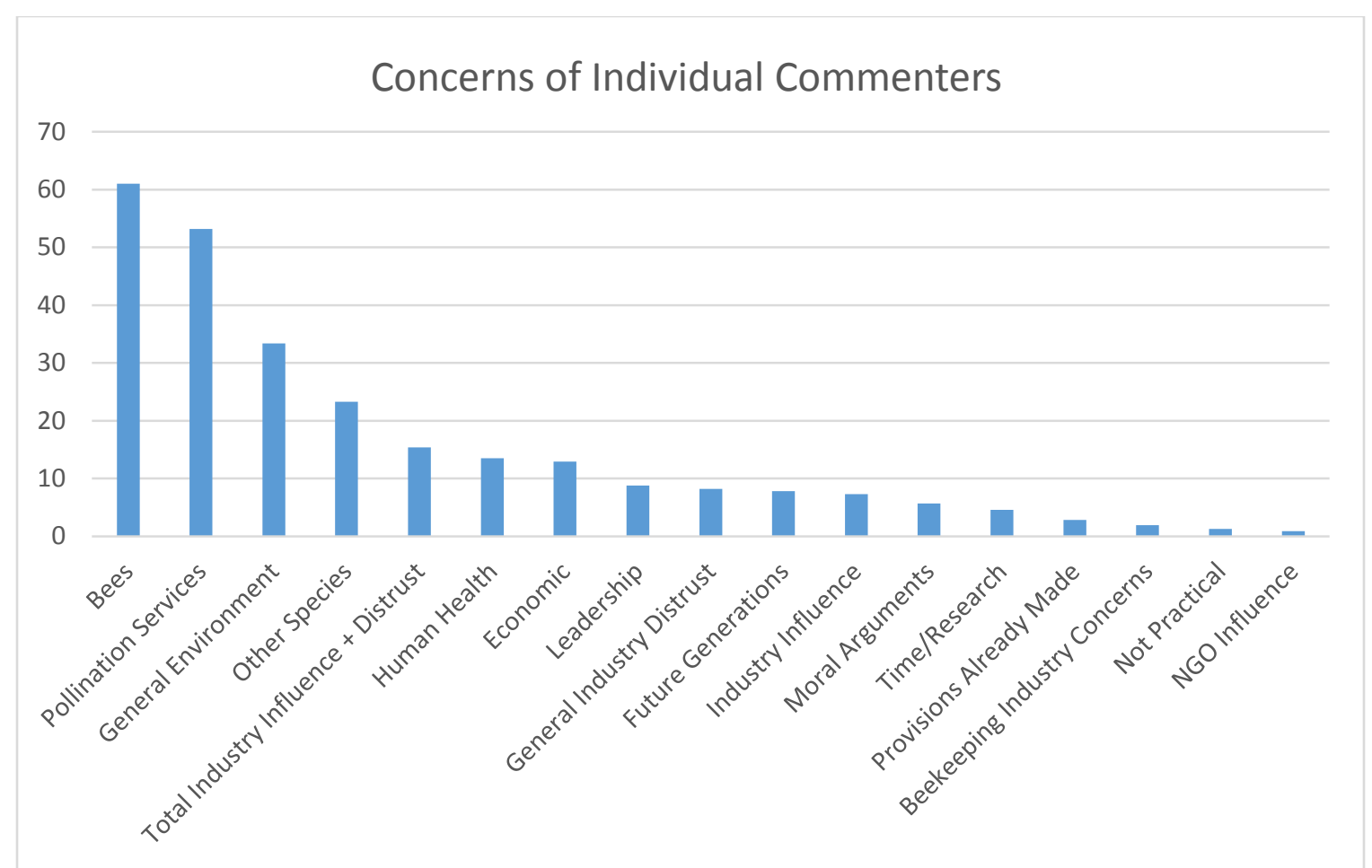

Figure 3: Percentages of individual commenters with each concern identified; percentages were calculated excluding commenters who did not cite any concern (187 out of 972 excluded). Descriptions of each category can be found in Table 2. 


\section{Types of Bees Mentioned}

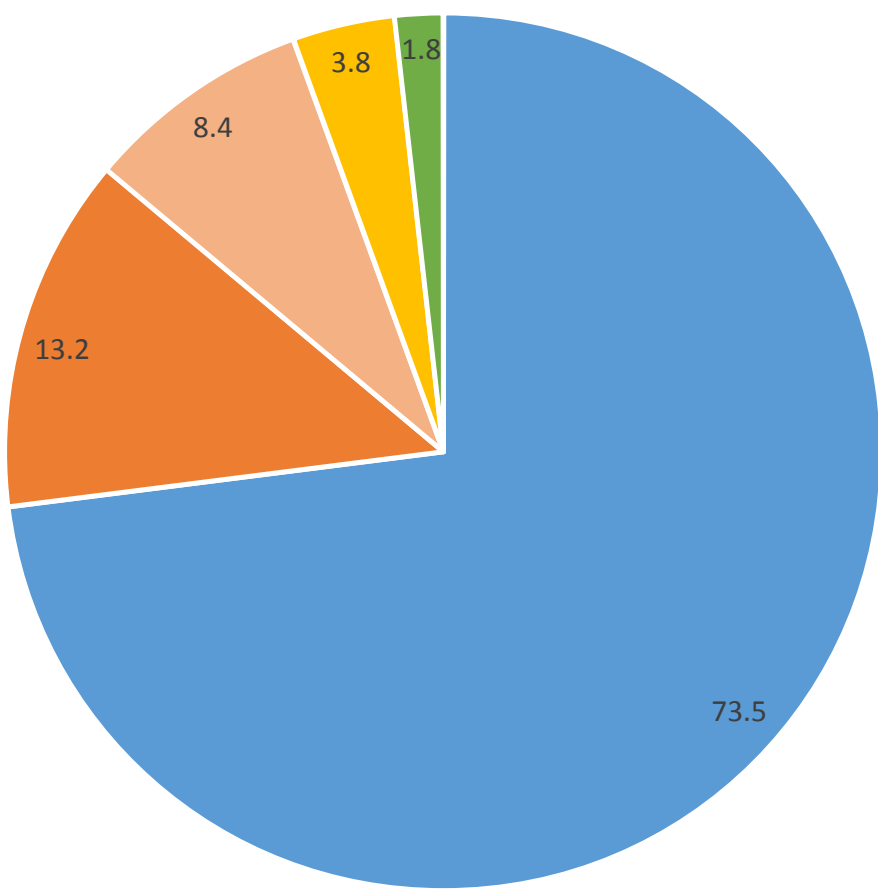

- "Bees" - Honeybees (implied) - Honeybees (explicit) - Other Bees • Bumblebees

Figure 4: Percentages of commenters mentioning bees by type of bee mentioned. In total, $61 \%$ of individual commenters with any concern mentioned bees. "Bees" refers to commenters who did not specify to which type of bee they were referring. 


\section{APPENDIX:}

1) Complete list of sources of information referenced by commenters and displayed in Figure 2, including description of each:

\begin{tabular}{|c|c|}
\hline Source of Information & Description \\
\hline Newspaper & Newspaper \\
\hline Website & Website (including news websites) \\
\hline Scientific & Peer-reviewed scientific journal article \\
\hline Anecdotal & $\begin{array}{l}\text { Refers to personal experience or personal conversations with } \\
\text { beekeepers, etc. }\end{array}$ \\
\hline Campaign & $\begin{array}{l}\text { References material from a campaign related to the proposal; } \\
\text { for example, a statement by the Green Party }\end{array}$ \\
\hline Quotation & $\begin{array}{l}\text { Provides a quotation; typically not directly related to the } \\
\text { proposal (e.g. quotations by Einstein or Chief Seattle) }\end{array}$ \\
\hline "science" & $\begin{array}{l}\text { Commenter refers to science/scientific research/research, } \\
\text { etc. without referencing a particular study or anything more } \\
\text { substantial }\end{array}$ \\
\hline Book & Book \\
\hline Past Cases & References to past experiences, such as DDT \\
\hline Elsewhere & References to experiences of other places (often Europe) \\
\hline Personal Study & $\begin{array}{l}\text { Refers to a study undertaken by the commenter, sometimes } \\
\text { with a local group; it was unclear from the redacted text } \\
\text { whether some of these were affiliated with a university or } \\
\text { other research group }\end{array}$ \\
\hline $\begin{array}{l}\text { Government/Government } \\
\text { Agency Reports }\end{array}$ & $\begin{array}{l}\text { Reports by government or government agencies, such as the } \\
\text { PMRA, EPA, etc. }\end{array}$ \\
\hline Film & Film (both fiction and documentary) \\
\hline NGO & Non-governmental organization \\
\hline Other & $\begin{array}{l}\text { All sources of information not falling under any of the above } \\
\text { categories }\end{array}$ \\
\hline
\end{tabular}


2) Concerns/motivations for commenting and percentages of commenters with each concern:

\begin{tabular}{|l|l|}
\hline Concerns/Motivations for Commenting & $\begin{array}{l}\text { Commenters Citing Each Concern (\%) } \\
\text { *percentages reported based on the 785 (of 972 } \\
\text { total) commenters who cited any concern }\end{array}$ \\
\hline Pollination Services & 53.2 \\
\hline Human Health & 13.5 \\
\hline Bees & 61.0 \\
\hline Other Species & 46.9 \\
\hline Provisions Already Made & 2.8 \\
\hline Moral Arguments & 5.7 \\
\hline Leadership & 8.8 \\
\hline Industry Influence & 7.3 \\
\hline Economic & 12.9 \\
\hline General Environment & 33.4 \\
\hline Time/Research & 4.6 \\
\hline NGO Influence & 0.9 \\
\hline Beekeeping Industry Concerns & 1.9 \\
\hline General Industry Distrust & 8.2 \\
\hline Not Practical & 1.3 \\
\hline Future Generations & \\
\hline Total Industry-related comments \\
Distrust)
\end{tabular}

